\title{
ANALISIS PENDAPATAN PETANI DAN FAKTOR-FAKTOR YANG MEMPENGARUHI PRODUKSI PADI SAWAH IRIGASI DI DESA SUMBEREJO KECAMATAN MEGANG SAKTI KABUPATEN MUSI RAWAS
}

\author{
May Shiska Puspitasari \\ Program Studi Agribisnis Fakultas Pertanian Universitas Musi Rawas \\ Koresponden e-mail: may270584@gmail.com
}

\begin{abstract}
ABSTRAK
Riset ini bertujuan untuk menghitung pendapatan usahatani padi sawah irigasi dan untuk mengidentifikasi faktor-faktor yang mempengaruhi produksi usahatani padi sawah irigasi di Desa Sumberejo Kecamatan Megang Sakti Kabupaten Musi Rawas. Pelaksanaan penelitian ini di Desa Sumberejo Kecamatan Megang Sakti di bulan September-Oktober 2018 dengan pertimbangan bahwa desa tersebut merupakan desa yang paling luas lahan sawahnya, serta produksi dan produktivitas tertinggi di Kecamatan Megang Sakti. Metode penelitian yang digunakan dengan metode survey dan penentuan tempat secara purposive. Jenis data yang dikumpulkan terdiri dari data primer dan sekunder. Metode pengumpulan data dengan melakukan survei terhadap $41 \mathrm{KK}$ yang di jadikan sampel dari total populasi sebesar $408 \mathrm{KK}$ dimana diambil secara proporsionate random sampling sebesar $10 \%$ dari total populasi yang dianggap sudah mewakili dari keseluruhan responden. Hasil penelitian diperoleh diketahui bahwa produksi rata-rata sebesar $2.297 \mathrm{Kg} / \mathrm{Ha}$, dengan rata-rata penerimaan petani $\mathrm{Rp}$. 19.252.207/Th dan pendapatan rata-rata sebesar Rp 14.710.552/Th. sedangkan produksi padi sawah irigasi dipengaruhi oleh 5 faktor diantaranya siginifikan pada taraf $\alpha 10 \%$ yaitu variabel luas lahan dan benih, sedangkan variabel pestisida signifikan pada taraf $\alpha 15 \%$ dan variabel yang tidak signifikan yaitu variabel pupuk dan tenaga kerja dengan nilai $\mathrm{R}$ square sebesar 90 yang berarti bahwa terdapat $10 \%$ dipengaruhi oleh variabel diluar model.
\end{abstract}

Kata Kunci : Biaya Produksi, Produksi, Pendapatan

\section{PENDAHULUAN}

\section{A. Latar Belakang}

Padi menjadi bahan pangan

kebutuhan pokok sebagian besar masyarakat Indonesia yang memberikan energi berupa karbohidrat. Padi menjadi komoditi ekonomi sumber penghasilan utama rata-rata petani, dan sebagai bahan makanan pokok untuk kebutuhan bagi sebagian besar masyarakat, sementara keberadaan padi ini sulit digantikan serta harus dalam jumlah yang cukup dalam memenuhi kebutuhan (Yanita dkk, 2011). Selain sebagai bahan pangan sumber karbohidrat, usahatani padi merupakan salah satu sumber pendapatan mayoritas penduduk, tinggi rendahnya pendapatan petani menjadi masalah yang bsutuh perhatian serius, hal ini disebabkan ratarata penduduk desa bekerja di sektor pertanian yang hasil produksi pertanian menjadi penghasilan utamanya. Upaya peningkatan pendapatan petani padi dipengaruhi oleh beberapa faktor diantaranya luas lahan, tenaga kerja dan penguasaan tentang teknologi dan sistem usahatani padi yang digunakan masyarakat juga menjadi berpengaruh terhadap tingkat pendapatan

Sistem pengairan padi sawah salah satunya adalah menggunakan irigasi teknis yang dilengkapi dengan alat pengatur dan pengukur air pada bangunan pengambilan, bangunan bagi dan bangunan sadap 
sehingga pengukuran air dapat teratur sampai bangunan bagi dan sadap dengan efisiensi yang tinggi. Sedangkan Irigasi setengah teknis adalah pemberian air pada lahan sawah secara sengaja dan teratur dengan tujuan menyediakan air bagi tanaman yang cukup dalam suatu periode apabila berkurang curah hujan alami. Pada kondisi kekurangan air, pengairan berbasis dapat meningkatkan unsur air pada tingkat siklus air untuk pertumbuhan tanaman. Apabila terjadi kelebihan dalam jumlah air yang tersedia, maka air dapat dibuang agar tidak ada genangan yang merugikan pertumbuahan tanaman. Jumlah cadangan air yang banyak dapat dipergunakan bagi pertumbuhan tanaman dengan waktu yang lama di masa mendatang, serta menjadi simpanan cadangan air. Dengan adanya sumber cadangan air ini perlu mendapat konservasi atau perlindungan (Supradjo, 1993).

Menurut Dinar (2018) adanya keberadaan irigasi menjadi salah satu pembantu pasokan air bagi tanaman padi, ketersediaan air menjadi berkurang saat musim kemarau yang mengakibatkan tidak meratanya dalam pembagian air untuk tanaman padi sawah, sehingga pemerintah berupaya untuk membangun saluran irigasi yang menghubungkan aliran sungai ke beberapa titik saluran tersier yang mengaliri wilayah persawahan. Di Desa Sumberejo Kecamatan Megang Sakti telah dibangun Irigasi yang sangat berperan dalam meningkatkan produksi padi sawah, yang menjadi sumber masalah utama pada saat musim kemarau menyebabkan jaringan irigasi ini terbatas ketersediaan air sehingga produksi padi yang dihasilkan menjadi rendah.

Masalah dalam jaringan irigasi diantaranya efisiensi distribusi air masih rendah terutama pada jaringan tersier, kurang tepat penerapannya manajemen operasional irigasi, serta biaya operasi juga pemeliharaan yang tidak mencukupi menyebabkan menurunnya fungsi jaringan irigasi dengan cepat. Adanya kombinasi penggunaan faktor-faktor produksi yang serasi dan pemanfaatan jaringan irigasi desa diharapkan produktivitas dan pendapatan usahatani padi sawah meningkat dan peningkatan pada kesejahteraan petani (Komarudin, 2010).

Kecamatan Megang Sakti adalah salah satu kecamatan di Kabupaten Musi Rawas yang masyarakatnya sebagai besar sumber pendapatan berasal dari usahatani padi. Berdasarkan data BPS Kabupaten Musi Rawas tahun 2018, salah satu desa yang paling luas lahan sawahnya adalah Desa Sumberejo yang memiliki luas panen 51.954 Ha, Produktivitas sebesar 5,36 Ton/Ha dan produksi sebesar 2.795 ton, padi sawah di Kecamatan Megang Sakti dapat dilakukan dalam satu tahun ada dua kali musim tanam dengan irigasi dan tadah hujan, sehingga penggunaan irigasi dapat mempengaruhi produksi padi sawah yang berpengaruh juga pada pendapatan petani. Berdasarkan uraian diatas maka penulis tertarik untuk melakukan riset dengan mengangkat judul Analisis Pendapatan Petani dan Faktor-Faktor yang Mempengaruhi Produksi Padi Sawah Irigasi Di Desa Sumberejo Kecamatan Megang Sakti Kabupaten Musi Rawas.

\section{B. Rumusan Masalah}

1. Menghitung pendapatan usahatani padi sawah irigasi Desa Sumberejo Kecamatan Megang Sakti Kabupaten Musi Rawas?

2. Mengidentifikasi faktor-faktor yang mempengaruhi produksi usahatani padi sawah irigasi di Desa Sumberejo Kecamatan Megang Sakti Kabupaten Musi Rawas?

\section{Tujuan}

1. Untuk menghitung pendapatan usahatani padi sawah irigasi Desa 
Sumberejo kecamatan Megang Sakti Kabupaten Musi Rawas

2. Untuk mengidentifikasi faktorfaktor yang mempengaruhi produksi usahatani padi sawah irigasi di Desa Sumberejo Kecamatan Megang Sakti Kabupaten Musi Rawas

\section{METODOLOGI PENELITIAN}

Penelitian ini dilaksanakan di Desa Sumberejo Kecamatan Megang Sakti pada bulan September-Oktober 2018 dengan pertimbangan bahwa desa tersebut merupakan desa yang paling luas lahan sawahnya, serta produksi dan produktivitas tertinggi di Kecamatan Megang Sakti. Metode penelitian yang digunakan dengan metode survey dan penentuan tempat secara purposive. Data yang dikumpulkan yaitu data primer yang berasal dari petani dengan tuntunan daftar kuisioner serta data sekunder yang bersumber dari beberapa literatur terkait dari BPS, Dinas Pertanian dan Peternakan, Instansi atau lembaga yang terkait dengan penelitian ini. Metode pengumpulan data dengan melakukan survei terhadap $41 \mathrm{KK}$ yang di jadikan sampel dari total populasi sebesar $408 \mathrm{KK}$ dimana diambil secara proporsionate random sampling sebesar $10 \%$ dari total populasi yang dianggap sudah mewakili dari keseluruhan responden.

Metode pengolahan data yaitu untuk menjawab rumusan masalah pertama yaitu menghitung pendapatan usahatani padi sawah irigasi di Desa Sumberejo Kecamatan Megang Sakti Kabupaten Musi Rawas digunakan rumus pendapatan yaitu

Pd $=$ TR - Bt

Dimana :

$\mathrm{Pd}=$ Pendapatan usahatani $(\mathrm{Rp} / \mathrm{Ha} / \mathrm{MT}$

$\mathrm{TR}=$ Total penerimaan $(\mathrm{Rp} / \mathrm{Ha} / \mathrm{MT})$

$\mathrm{Bt}=$ Biaya yang di bayarkan $(\mathrm{Rp} / \mathrm{Ha} / \mathrm{MT})$
Untuk menjawab rumusan masalah yang kedua yaitu faktor-faktor yang mempengaruhi produksi usahatani padi sawah irigasi di Desa Sumberejo Kecamatan Megang Sakti Kabupaten Musi Rawas digunakan regeresi berganda sebagai berikut ;

$$
\begin{aligned}
\operatorname{Ln} Y= & \operatorname{Ln} A+\beta_{1} \operatorname{Ln} X_{1}+\beta_{2} \operatorname{Ln} X_{2}+\beta_{3} \\
& \operatorname{Ln} X_{3}+\beta_{4} \operatorname{Ln} X_{4}+\beta_{5} \operatorname{Ln} X_{5} \mathrm{e}
\end{aligned}
$$

Dimana : $\mathrm{Y}=$ Produksi

$\mathrm{A}=$ Konstanta

$\beta=$ Koefisien Regresi

$\mathrm{X} 1=$ Luas Lahan $(\mathrm{Ha})$

$\mathrm{X} 2=$ Benih $(\mathrm{Kg})$

$\mathrm{X} 3=$ Pupuk $(\mathrm{Kg})$

$\mathrm{X} 4=$ Pestisida $(\mathrm{lt})$

$\mathrm{X} 5$ = Tenaga Kerja (HOK)

$\mathrm{e} \quad=$ Kesalahan Pengganggu (Error tern)

kemudian dilanjutkan dengan uji $\mathrm{F}$ untuk mengetahui variabel independen secara bersama-sama terhadap variabel dependen dan untuk mengetahui variabel secara parsial dilakukan dengan uji t.

\section{HASIL DAN PEMBAHASAN}

\subsection{Karakteritik Responden}

Responden yang diwawancarai dalam penelitian ini merupakan petani padi sawah yang ada di Kabupaten Musi Rawas. Kecamatan Megang Sakti dipilih sebagai salah satu kawasan yang mayoritas penduduknya berusahatani padi sawah yang menggunakan irigasi. Klasifikasi luas lahan petani, dari 41 responden dilihat pada Tabel 3.1 dan karakteristik lainnya dari responden dapat dilihat dari beberapa variabel yaitu umur, tingkat pendidikan, jumlah tanggungan, dan status lahan sawah. Berikut penjelasan berdasarkan Tabel di bawah ini : 
Tabel 3.1 Jumlah responden berdasarkan luas lahan di Desa Sumberejo Kecamatan Megang Sakti

\begin{tabular}{llll}
\hline Uraian & Luas Lahan (Ha) & $\begin{array}{c}\text { Responden } \\
(\mathrm{Org})\end{array}$ & Proporsi (\%) \\
\hline \multirow{3}{*}{ Desa Sumberejo } & $0,25-0,5$ & 14 & 22,2 \\
& $0,6-1,0$ & 25 & 39,68 \\
& $1,1-1,5$ & 2 & 3,17 \\
\hline
\end{tabular}

Sumber : Lampiran 1

Berdasarkan Tabel 3.1 bahwa luas lahan di daerah penelitian diperoleh data untuk responden di Desa Sumberejo dengan luas lahan $0,25-0,5$ Ha sebanyak 14 orang atau $22,2 \%$, luas lahan $0,6-1,0$ Ha sebanyak 25 orang atau sebesar 39,68\% dan luas lahan 1,1-1,5 Ha sebanyak 2 orang atau 3,17\%,
Hal ini berarti lahan di Kecamatan Megang Sakti masih luas untuk pertanian. Sedangkan untuk karakteristik responden dari variabel umur, tingkat pendidikan, jumlah tanggungan keluarga disajikan pada tabel 3.2 di bawah ini :

Tabel 3.2. Penyebaran Kerakteristik Responden

\begin{tabular}{|c|c|c|c|}
\hline No & Uraian & Jumlah Responden (Orang) & Proporsi $(\%)$ \\
\hline \multirow{5}{*}{1.} & Desa Sumberejo & & \\
\hline & Umur & & \\
\hline & $30-40$ & 11 & 26,82 \\
\hline & $41-50$ & 20 & 48,78 \\
\hline & $51-60$ & 10 & 24,39 \\
\hline \multirow[t]{4}{*}{2.} & Tingkat Pendidikan & & \\
\hline & Tamat SD & 13 & 31,70 \\
\hline & Tamat SMP & 19 & 46,34 \\
\hline & Tamat SMA & 9 & 21,95 \\
\hline \multirow[t]{4}{*}{3} & Jumlah Tanggungan & & \\
\hline & $1-2$ & - & - \\
\hline & $3-4$ & 27 & 65,85 \\
\hline & $5-6$ & 14 & 36,58 \\
\hline
\end{tabular}

Sumber : Lampiran 1

Pada Tabel 3.2 dapat diketahui bahwa umur responden untuk berdasarkan pengelompokan umur berdasarkan interval terbagi menjadi 3 yaitu untuk di Desa Sumberejo kisaran umur 30-40 sebanyak 11 orang atau $26,82 \%$, kisaran umur 41 50 sebanyak 20 orang atau $48,78 \%$ dan kisaran umur 51-60 sebanyak 10 orang atau $24,39 \%$. Selain dari variabel umur, keadaan umum responden penelitian juga bisa dilihat dari tingkat pendidikan yang berhasil mereka tamatkan. Untuk tingkat pendidikan yaitu tamat SD sebanyak 13 orang atau $31,70 \%$, tamat SMP sebanyak 19 orang atau 46,34 \%, tamat SMA sebanyak 9 orang atau $21,95 \%$. Untuk jumlah tanggungan berkisar 3-4 sebanyak 27 orang atau 65,85\% dan kisaran 5-6 sebanyak 14 orang atau 36,5 .

\subsection{Biaya Produksi}


Biaya produksi merupakan biaya yang dibutuhkan dalam usahatani padi sawah, biaya produksi ada 2 macam yaitu biaya tetap dan biaya variabel, biaya yang dihitung ini adalah biaya produksi 2 musim tanam selama 1 tahun, untuk lebih jelasnya di sajikan pada Tabel dibawah ini

Tabel. 3.3. Hasil perhitungan biaya produksi untuk usahatani padi sawah petani irigasi di Desa Sumberejo di Kecamatan Megang Sakti

\begin{tabular}{lll}
\hline No & Uraian & Rata-rata Biaya \\
\hline 1 & Biaya Tetap & Rp. 140.110 \\
2 & Biaya Tenaga Kerja & Rp. 3.523 .868 \\
3 & Biaya Saprodi & Rp. 877.678 \\
\hline & Biaya Total & Rp.4.541.655 \\
\hline
\end{tabular}

Dari tabel 3.3 diatas dapat diketahui bahwa biaya tetap rata-rata usahatani padi sawah sebesar Rp. 140.110 dan biaya variabel rata-rata untuk tenaga kerja sebesar Rp. 3.523.868 biaya variabel rata-rata untuk saprodi sebesar Rp. 877.678 sehingga diperoleh biaya total rata-rata sebesar Rp. 4.541.655.

\subsection{Produksi, Penerimaan dan Pendapatan}

Dalam usahatani padi sawah, produksi yang tinggi akan meningkatkan penerimaan dan pendapatan petani, dimana semakin tinggi pendapatan petani maka petani akan semakin sejahtera kehidupannya. Berikut ini rata-rata produksi, penerimaan dan pendapatan petani padi sawah irigasi yang di sajikan pada Tabel 3.4 berikut ini :

Tabel 3.4 Produksi, Penerimaan dan Pendapatan usahatani padi sawah irigasi di Desa Sumberejo di Kecamatan Megang Sakti

\begin{tabular}{lll}
\hline No & \multicolumn{1}{c}{ Uraian } & \\
\hline 1 & Produksi & Rata-rata \\
2 & Penerimaan & Rp. 19.252 .207 \\
3 & Pendapatan & Rp. 14.710 .552 \\
\hline
\end{tabular}


Dari Tabel diatas diketahui bahwa produksi rata-rata sebesar $2.297 \mathrm{Kg} / \mathrm{Ha}$, dengan rata-rata penerimaan petani $\mathrm{Rp}$. 19.252.207/Th dan pendapatan rata-rata sebesar Rp 14.710.552. pendapatan perorangan merupakan pendapatan yang diterima oleh rumahtangga dan usaha yang bukan perusahaan. Pendapatan juga sangat dipengaruhi oleh besarnya penerimaan dan biaya dalam usahatani, sehingga semakin besar biaya yang dikeluarkan dalam usahatani semakin kecil pula penerimaan usahatani yang mempengaruhi besar kecilnya tingkat pendapatan petanin (Mankiw, 2006).

\subsection{Faktor-faktor yang mempengaruhi produksi padi sawah irigasi}

Tinggi rendah produksi padi dipengaruhi oleh banyak faktor, pada penelitian ini ada 5 variabel yang mempengaruhi produksi padi sawah irigasi terdiri dari luas lahan, benih, pupuk, pestisida dan tenaga kerja, yang mana ke 5 variabel ini di uji regresi untuk mengetahui variabel yang berpengaruh terhadap produksi, lebih jelasnya disajikan pada Tabel 3.5 di bawah ini :

Tabel 3.5 Hasil Regresi faktor-faktor yang mempengaruhi produksi petani

\section{Coefficients $^{\mathrm{a}}$}

\begin{tabular}{|c|c|c|c|c|c|c|c|}
\hline \multirow[b]{2}{*}{ Model } & \multicolumn{2}{|c|}{$\begin{array}{l}\text { Unstandardized } \\
\text { Coefficients }\end{array}$} & $\begin{array}{l}\text { Standardized } \\
\text { Coefficients }\end{array}$ & \multirow[b]{2}{*}{$\mathrm{t}$} & \multirow[b]{2}{*}{ Sig. } & \multicolumn{2}{|c|}{ Collinearity Statistics } \\
\hline & B & Std. Error & Beta & & & Tolerance & VIF \\
\hline 1 (Constant) & 13.027 & 49.081 & & .265 & .792 & & \\
\hline Luas Lahan & 2081.870 & 616.466 & 1.016 & 3.377 & .002 & .005 & 220.586 \\
\hline Benih & 10.739 & 5.690 & .193 & 1.887 & .067 & .039 & 25.530 \\
\hline Pupuk & -.044 & .253 & -.010 & -.175 & .862 & .117 & 8.520 \\
\hline Pestisida & 78.918 & 52.618 & .078 & 1.500 & .143 & .150 & 6.652 \\
\hline Tenaga Kerja & -4.708 & 4.521 & -.275 & -1.041 & .305 & .006 & 169.736 \\
\hline
\end{tabular}

a. Dependent Variable: Produksi

Dari hasil perhitungan dengan menggunakan program SPSS dapat diketahui bahwa hasil uji t untuk variabel luas lahan (X1) diperoleh hasil t hitung sebesar 3.377 dengan nilai probabilitas 0.02 dengan demikian ada pengaruh yang signifikan antara luas lahan dengan produksi. Luas lahan berpengaruh terhadap pendapatan petani. Luas lahan akan mempengaruhi skala usaha yang pada akhirnya akan mempengaruhi besar atau kecilnya jumlah produksi suatu usaha pertanian. Besar atau kecilnya jumlah produksi suatu usaha pertanian akan mempengaruhi pendapatan petani, dimana petani yang mempunyai luas lahan yang luas akan mendapatkan hasil produksi yang banyak sehingga memperoleh penghasilan yang banyak pula, sedangkan petani yang memiliki luas lahan yang sedikit maka produksinya juga sedikit dengan penghasilan yang sedikit pula.

Hasil uji t untuk variabel benih (X2) diperoleh hasil $\mathrm{t}$ hitung sebesar 1.887 dengan probabilitas sebesar 0.067 dengan demikian ada pengaruh yang signifikan antara benih (X2) dengan produksi padi (Y). Berdasarkan hasil penelitian Neonbota (2016) bahwa t hitung (0.236) < t tabel (1.664) dengan demikian Ha ditolak dan Ho diterima. Maka dapat disimpulkan bahwa benih secara parsial dapat berpengaruh terhadap produksi padi sawah tetapi tidak nyata. Hal ini disebabkan karena nilai koefisien regresi sebesar (0.025) menunjukan adanya pengaruh karena nilai $\mathrm{t}$ hitung $(0.858)<\mathrm{t}$ table (1.664) hal ini berarti apabila peningkatan 
benih akan meningkatkan produksi yakni setiap kenaikan jumlah benih 1 satuan akan meningkatkan produksi sebesar (0.025) $\mathrm{kg}$ bila faktor-faktor lain dianggap tetap.

Hasil uji t untuk variabel pupuk (X3) diperoleh hasil $\mathrm{t}$ hitung sebesar -175 dengan probabilitas sebesar 0,86 Nilai probabilitas lebih besar dari $\alpha 10 \%$ dengan demikian tidak ada pengaruh yang signifikan antara pupuk (X3) dengan produksi padi petani (Y). Hal ini berarti bahwa penggunaan pupuk tidak berpengaruh terhadap peningkatan produksi padi sawah dan dengan nilai $t$ hitung yang negatif menyatakan hubungan yang berlawanan arah, semakin tinggi penggunaan pupuk justru akan mengurangi produksi padi sawah, karena penggunaan pupuk yang berlebihan tidak sesuai dosis akan menurunkan produksi padi sawah.

Hasil uji t untuk variabel pestisida (X4) diperoleh hasil $\mathrm{t}$ hitung sebesar 1.500 dengan probabilitas sebesar 0,14 Nilai probabilitas lebih kecil dari $\alpha 15 \%$ dengan demikian ada pengaruh yang signifikan antara pestisida (X4) dengan produksi padi petani (Y). Selaras dengan hasil penelitian Mahananto dkk (2009) bahwa penggunaan pestisida pada MT I belum mencapai tingkat efisiensi ekonomis, hal ini bisa dilihat dari nilai $\mathrm{k}$ yang lebih besar dari pada 1, sehingga penggunaannya perlu ditambah. Masih rendahnya penggunaan faktor produksi pestisida dalam proses produksi di daerah penelitian ini kemungkinan disebabkan oleh miskinnya petani sehingga tidak sanggup untuk membeli pestisida atau kemungkinan petani tidak tanggap terhadap arti pentingnya faktor produksi pestisida didalam menunjang proses produksi.

Hasil uji t untuk variabel tenaga kerja (X5) diperoleh hasil $\mathrm{t}$ hitung sebesar -1.041 dengan probabilitas sebesar 0,30 dengan demikian tidak ada pengaruh yang signifikan antara tenaga kerja (X5) dengan produksi padi petani (Y). Sejalan dengan hasil penelitian Damanik (2014) bahwa pengaruh tenaga kerja berpengaruh positif dan tidak signifikan terhadap pendapatan petani padi di Kecamatan Masaran, Kabupaten Sragen. Artinya bahwa jumlah tenaga kerja berpengaruh tetapi tidak signifikan terhadap pendapatan petani padi. Hal ini disebabkan karena sistem kerja pada daerah penelitian adalah sistem borongan. Sejalan juga dengan penelitian Muzdalifah (2014) diperoleh hasil uji statistik menunjukkan bahwa t-hitung < ttabel $(1,197<2,045)$ pada tingkat kepercayaan 95\%. Hal ini menunjukkan bahwa variabel tenaga kerja (X5) tidak berpengaruh nyata terhadap produksi padi sawah dikarenakan tenaga kerja yang digunakan oleh petani padi sawah di Desa Sidera belum sesuai karena kurang memperhatikan kualitas tenaga kerja.

\subsection{Pengujian Secara Bersama (uji F)}

Uji hipotesis secara bersama-sama (Uji F) antara variabel bebas dalam hal ini antara luas lahan (X1), benih (X2), pupuk (X3), pestisida (X4), tenaga kerja (X5), diperoleh hasil berikut ini: 
Tabel 3.6 Hasil Perhitungan Uji F

\begin{tabular}{|rl|r|r|r|r|r|}
\hline \multicolumn{1}{|c|}{ ANOVA $^{\mathbf{b}}$} & \\
\hline 1 & Sum of Squares & df & Mean Square & \multicolumn{1}{c|}{$\mathrm{F}$} & \multicolumn{1}{c|}{ Sig. } \\
\hline & Regression & $1.098 \mathrm{E} 7$ & 5 & 2196987.865 & 480.775 & $.000^{\mathrm{a}}$ \\
& Residual & 159938.722 & 35 & 4569.678 & & \\
& Total & $1.114 \mathrm{E} 7$ & 40 & & & \\
\hline
\end{tabular}

a. Predictors: (Constant), Tenaga Kerja, Pestisida, Pupuk, Benih, Luas Lahan

b. Dependent Variable: Produksi

Dari Tabel diatas diperoleh nilai $\mathrm{F}$ hitung 480.775 dengan probabilitas 0,000 , dimana nilai probabilitas lebih kecil dari 0,01 maka nilai $\mathrm{F}$ hitung tersebut signifikan. Disimpulkan bahwa ada pengaruh yang signifikan antara luas lahan (X1), benih (X2), pupuk (X3), pestisida (X4), dan tenaga kerja (X5) sesuai dengan hasil penelitian dari Damanik, (2014) hasil uji F sebesar 860,3790 dan nilai prob. F-hitung $(0,000000) \alpha 10 \%$ dengan variabel luas lahan, jumlah tenaga kerja, dan biaya produksi yang secara bersama-sama berpengaruh dan signifikan terhadap pendapatan petani padi di Kecamatan Masaran.

\subsection{Uji Koefisien Determinasi (R2)}

Besarnya pengaruh luas lahan, benih, pupuk, pestisida dan tenaga kerja terhadap produksi padi petani di Desa Sumberejo Kecamatan Megang Sakti diketahui dari harga koefisien determinasi simultan (R2) sebesar 0,90 berarti data tersebut menunjukkan bahwa variasi persentase total dalam variabel $\mathrm{Y}$ (produksi) padi petani di Kecamatan Megang Sakti dapat dijelaskan oleh variabel X luas lahan (X1), benih (X2), pupuk (X3), pestisida (X4), tenaga kerja (X5) sebesar $90 \%$. Sisanya $10 \%$ adalah dipengaruhi variabel lain diluar model sejalan dengan hasil penelitian dari Ivans, Eny dkk (2013) bahwa diperoleh nilai R2 sebesar 0,947. Hal ini berarti 94 persen variasi produksi padi sawah di lokasi penelitian dapat dijelaskan oleh variasi dari variabel independen seperti luas lahan, benih, pupuk urea, pupuk NPK, pupuk SP36, pupuk organik, insektisida, fungisida, herbisida dan tenaga kerja sedangkan sisanya sebesar $6 \%$ dijelaskan oleh sebab-sebab lain diluar model.

\section{KESIMPULAN DAN SARAN}

\subsection{Kesimpulan}

1. Hasil perhitungan diperoleh rata-rata pendapatan petani padi sawah irigasi sebesar Rp. 14.710.552/th. Semakin tinggi produksi padi sawah maka akan semakin tinggi pula pendapatan yang diterima oleh petani padi sawah.

2. Produksi padi sawah irigasi dipengaruhi oleh 5 variabel yang 2 diantaranya siginifikan pada taraf $\alpha 10 \%$ yaitu variabel luas lahan dan benih, sedangkan pada taraf $\alpha 15 \%$ ada 1 variabel yang signifikan yaitu variabel pestisida dan selebihnya ada 2 variabel yang tidak signifikan yaitu variabel pupuk dan tenaga kerja dan nilai $\mathrm{R}$ square sebesar 90 yang berarti bahwa terdapat $10 \%$ dipengaruhi oleh variabel diluar model. 


\subsection{Sarannya}

1. Agar petani mengoptimalkan pengolahan lahan yang ada untuk meningkatkan hasil produksinya.

2. Setiap rumhatangga petani harus untuk memiliki sumber penghasilan selain padi sawah irigasi untuk meningkatkan pendapatan dan kesejahteraan petani.

\section{DAFTAR PUSTAKA}

Badan Pusat Statistik. 2018. Kabupaten Musi Rawas dalam Angka. Kabupaten Musi Rawas.

Badan Pusat Statistik 2018. Kecamatan Megang Sakti dalam Angka. Kabupaten Musi Rawas

Dinar. 2018. Pengaruh Sistem Irigasi

Terhadap Pendapatan Usahatani Padi Sawah (Oryza sativa L.) Jurnal Ilmu Pertanian dan Peternakan Volume 6 Nomor 2 Desemeber 2018.

Damanik, Joni Arman. 2014. Analisis Faktor-Faktor Yang Mempengaruhi Pendapatan Petani Padi Di Kecamatan Masaran, Kabupaten Sragen. Economics Development Analysis Journal 3 (1) (2014).

Ivans, Eny, Wan Abbas Zakaria, Helvi Yenfika. 2013. Analisis Usahatani Padi Sawah Pada Irigasi Desa Di Kecamatan Purbolinggo Kabupaten Lampung Timur. Jurnal JIIA, Volume 1 No. 3, Juli 2013.

Komarudin, Roni. 2010. Peningkatan Kinerja Jaringan Irigasi Melalui Penerapan Manajemen yang Tepat dan Konsisten pada Daerah Irigasi Ciramajaya. Jurnal Teoretis dan Terapan Bidang Rekayasa Sipil Vol. 17 No. 2 Agustus 2010
Mankiw, N.Gregory. 2006. Teori Makroekonomi. Erlangga. Jakarta

Mahananto, Salyo Sutrisno dan Candra F Ananda. 2009. Faktor-Faktor Yang Mempengaruhi Produksi Padi Studi Kasus Di Kecamatan Nogosari, Boyolali, Jawa Tengah. Jurnal WACANA Vol. 12 No.1 Januari 2009.

Muzdalifah. 2014. Pengaruh Irigasi Terhadap Produksi Usahatani Padi Sawah Di Desa Siderakecamatan Sigibiromaru. Jurnal E-J.Agrotekbis 2 (1) : 76-84, Edisi Februari 2014.

Neonbotaa, Serafina Laka, Simon Juan Kune. 2016. Faktor-Faktor Yang Mempengaruhi Usahatani Padi Sawah Di Desa Haekto Kecamatan Noemuti Timur. Jurnal Agribisnis Lahan Kering Agrimor 1 (3) 32-35.

Supradjo, P dan Sahid, S. 1993. Prespektif

Dari Pengembangan Manajemen

Sumber Air dan Irigasi Untuk

Pengembangan Pertanian.Leberty.

Yogyakarta.

Yanita Mirawati, SuryantyMelli, FaridaAulia, 2011. Kajian Efisiensi Ekonomi Usahatani Padi Sawah Di Kecamatan Air Hangat Kabupaten Kerinci. Fakultas Pertanian, Universitas Jambi. 